w nadmorskiej miejscowości uprawiająca jogging, jeżdżąca dla przyjemności na rowerze, grająca w tenisa ziemnego jest tradycyjnym turystą wypoczynkowym, czy być może już turystą sportowym?

Wydaje się uzasadnione uznanie za turystykę sportową tylko i wyłącznie te wyjazdy, dla których głównym motywem jest bierny udział $\mathrm{w}$ wydarzeniach sportowych (kibice) lub czynny udział $\mathrm{w}$ amatorskich imprezach sportowych (np. maratonach biegowych, spływach, rajdach). Pozostałe typy wyjazdów trudno nazwać turystyką sportową, bowiem uczestniczą w nich sportowcy zawodowcy (efekt komercyjny) albo osoby, dla których głównym celem jest sport jako taki, a nie te elementy, które od dawna przypisane są turystyce. Niełatwo także znaleźć granicę pomiędzy pojęciami dotąd funkcjonującymi w terminologii turystycznej, takimi jak: „turystyka kwalifikowana", "turystyka aktywna" a pojęciem „turystyka sportowa". Podobnie trudno jest wskazać umiejętności (predyspozycje), jakie powinni posiadać uczestnicy turystyki sportowej.

Turyści biorący udział w tzw. turystyce sportowej korzystają najczęściej z ogólnej infrastruktury turystycznej (noclegi, baza gastronomiczna, transport, informacja turystyczna) oraz z urządzeń sportowo-rekreacyjnych dostępnych dla wszystkich turystów, niezależnie od motywacji ich przyjazdów do miejsc wypoczynku. Tylko niewielka część bardzo specjalistycznych urządzeń sportowo-rekreacyjnych adresowana jest do osób mających konkretne umiejętności (np. mariny żeglarskie, ścianki wspinaczkowa, tory kolarskie itp.), ale nawet z tych obiektów i urządzeń mogą korzystać turyści, którzy przyjeżdżają na wakacje, weekendy, czyli są dla mnie tradycyjnymi turystami.

W związku z niemożnością jednoznacznego, precyzyjnego zdefiniowania turystyki sportowej, trudno określić skalę i sezonowość tego zjawiska, a także miary pozwalające wskazać, jaka część ogółu podróży turystycznych może być zaliczana do tzw. turystyki sportowej. W miarę proste wydaje się oszacowanie liczby turystów-kibiców na najważniejszych międzynarodowych imprezach sportowych (na imprezach krajowych już zdecydowanie trudniej), natomiast określenie skali tego typu zjawiska podczas wyjazdów urlopowo-wakacyjnych czy weekendowych jest zadaniem karkołomnym, a zdaniem piszącego te słowa także zbytecznym.

Reasumując swoje rozważania pragnę podkreślić raz jeszcze, że turystyka jest postrzegana jako zjawisko interdyscyplinarne, co wynika z różnorodnych motywacji osób wyjeżdżających poza zwykłe swoje otoczenie, w szeroko rozumianych celach wypoczynkowych, ale nie oznacza to, iż funkcjonują niejako niezależne od siebie "różne turystyki", w tym turystyka sportowa.

Coraz częściej w naukowej terminologii dotyczącej turystyki pojawiają się nowe, „modne” pojęcia niemające uzasadnienia naukowego, a wprowadzające do tejże terminologii istotny chaos semantyczny. Do takich pojęć zaliczam także "turystykę sportową", określenie robiące obecnie karierę w polskiej literaturze turystycznej, określenie, które próbuje przekształcić dotychczasowe pojęcia "turystyka kwalifikowana" i „turystyka aktywna” w jeden syntetyczny agregat pojęciowy, niestety bez pozytywnego rezultatu.

\title{
Bibliografia
}

SMITH A., 2001, Sporting a new image? Sport-based regeneration strategies as a means of enhancing the image of the city tourist destination, [w:] Sport in The City. The role of sport in economic and social regeneration, Ch. Gratton, I. Henry (eds.), Routledge, London.

STANDEVEN J., DE KNOP P., 1999, Sport Tourism, Human Kinetics, Champaign, Illinois.

WEED M.E., BULL C.J., 2004, Sport tourism: Participant, policy and provider, Elsevier Butterworth-Heinemann, Oxford.

http://dx.doi.org/10.18778/0867-5856.26.1.12

\author{
Leszek Butowski \\ Uniwersytet Warmińsko-Mazurski w Olsztynie
}

\section{TURYSTYKA SPORTOWA - BYT RZECZYWISTY CZY WIRTUALNY?}

W polskiej literaturze przedmiotu jeszcze w latach $70 . \mathrm{XX}$ w. ukształtował się podział turystyki ze względu na motywy podejmowanych podróży oraz rodzaj wykorzystywanych walorów turystycznych. Zgodnie z tymi kryteriami wyróżniono: turystykę wypoczynkową (wypoczynkowy motyw wyjazdów), turystykę krajoznawczą (motyw poznawczy) oraz turystykę kwalifikowaną (możliwość realizacji hobby, pasji itp.) (ROGALEWSKI 1974). Podział ten, choć obecnie trochę anachroniczny, pozostaje $\mathrm{w}$ jakimś stopniu przydatny zwłaszcza do celów dydaktycznych. Jego głównym mankamentem jest jednak niekompletność. Nie obejmuje on bowiem pewnych nowych form turystyki, których dynamiczny rozwój nastąpił w ostatnich dekadach. Jego niekompletność wynika także z rozszerzenia samej definicji turystyki, która zaczęła obejmować również np. podróże $\mathrm{w}$ interesach (tzw. turystyka biznesowa). Wydaje się jednak, że w celu przeprowadzenia dyskusji nad zakresem znaczeniowym 
pojęcia „turystyka sportowa” tradycyjny podział na turystykę krajoznawczą i kwalifikowaną może okazać się przydatny.

Zacznijmy jednak od nakreślenia pewnych ram znaczeniowych dla samego pojęcia "turystyka sportowa”. W literaturze przedmiotu obejmuje ono zwykle cztery formy aktywności turystycznej (BOŃCZAK 2013a, GIBSON 1998, s. 45, MOKRAS-GRABOWSKA 2015, s. 121-122), tj.: 1) wyjazdy w celu oglądania wydarzeń sportowych (tzw. fanoturystyka); 2) wyjazdy w celu zwiedzania obiektów sportowych (np. słynnych stadionów, niekoniecznie podczas wydarzeń sportowych); 3) wyjazdy w celu uczestnictwa w imprezach sportowych jako zawodnicy1; 4) wyjazdy w celu uprawiania różnych form aktywności sportowej (bez elementów współzawodnictwa²). Nawet pobieżna analiza wymienionych form turystyki sportowej pokazuje, że każdą z nich można przyporządkować do jednego z wcześniej wymienionych rodzajów turystyki. I tak, wyjazdy w celu zwiedzania obiektów sportowych jako swoistych walorów (atrakcji) turystycznych to typowy przykład turystyki krajoznawczej. Podobnie rzecz się ma jeśli idzie o tzw. fanoturystykę. Stanowi ona odmianę turystyki krajoznawczej o charakterze kulturowym (wydarzenie sportowe jako element kultury masowej). Z kolei zarówno czynne uczestnictwo w zawodach sportowych, jak i uprawianie aktywności sportowych bez elementu współzawodnictwa spełniają tradycyjne kryteria turystyki kwalifikowanej (odpowiednie kwalifikacje uczestników, umiejętność obsługi wyspecjalizowanego sprzętu). W powyższym kontekście widać, że poszczególne formy tzw. turystyki sportowej mają niejednorodny charakter, mimo że często występują pod tą samą nazwą (tab. 1).

Tab. 1. Relacje między tradycyjnymi rodzajami turystyki a formami turystyki sportowej

\begin{tabular}{|l|l|}
\hline \multicolumn{1}{|c|}{ Rodzaje turystyki } & \multicolumn{1}{|c|}{ Odpowiadające im formy turystyki sportowej } \\
\hline $\begin{array}{l}\text { Turystyka } \\
\text { krajoznawcza }\end{array}$ & Zwiedzanie obiektów sportowych \\
\cline { 2 - 2 } Turystyka & Oglądanie wydarzeń sportowych (fanoturystyka) \\
kwalifikowana & Uczestnictwo w zawodach sportowych jako zawodnicy \\
\cline { 2 - 2 } & $\begin{array}{l}\text { Uprawianie różnych form aktywności sportowej (bez } \\
\text { elementów współzawodnictwa) }\end{array}$ \\
\hline
\end{tabular}

Źródło: opracowanie własne.

Ta siłą rzeczy krótka analiza terminologiczna określająca przynajmniej ramowo zakres znaczeniowy pojęcia "turystyka sportowa”, a także jego relacje z innymi rodzajami turystyki, może stanowić podstawę do sformułowania pewnych bardziej ogólnych wniosków. Po pierwsze, czy uprawnione jest używanie terminu "turystyka sportowa” (w takim znaczeniu jak pojawia się on we współczesnej literaturze)? Wydaje się, że z poznawczego punktu widzenia nie ma to należytego uzasadnienia i może wprowadzać wiele terminologicznego chaosu. Termin "turystyka sportowa" obejmuje bowiem (jak wykazano wcześniej) różne odległe od siebie pod względem genetycznym formy turystyki. Natomiast w celu precyzyjnego opisu pewnych stosunkowo nowych zjawisk (form) turystycznych niezbędne jest jednoznaczne uściślenie tego, jaka forma turystyki związana z aktywnością sportową stanowi przedmiot naszego zainteresowania.

Konkluzja powyższa oznacza, że w sensie ontologicznym nie ma czegoś takiego jak turystyka sportowa. Istnieją natomiast różne formy turystyki, które wykazują pewne związki z aktywnością sportową. Są one jednak od siebie na tyle odległe, że trudno znaleźć dla nich wspólny mianownik. Cóż bowiem wspólnego (w sensie poznawczoepistemologicznym) może mieć wyjazd tzw. kiboli na mecz piłki nożnej ich drużyny do sąsiedniego miasta z rejsem żeglarskim dookoła świata? Jedna i druga forma mieści się natomiast w pojęciu "turystyka sportowa”, tak jak jest ono rozumiane w wielu pozycjach literatury.

Mając na uwadze powyższe wnioski należałoby wykonać w odniesieniu do poszczególnych form tzw. turystyki sportowej - przynajmniej tych, które wyróżniono w niniejszej wypowiedzi - bardziej szczegółowe analizy dotyczące predyspozycji do jej uprawiania, znaleźć możliwe do wykorzystania mierniki, określić niezbędną infrastrukturę czy też perspektywy rozwojowe.

\footnotetext{
${ }^{1}$ Pojawiają się tu pewne wątpliwości czy tego typu podróże można zakwalifikować do podróży turystycznych, ponieważ znaczna ich część ma charakter zawodowy (sport profesjonalny) (BOŃCZAK 2013b). Niemniej jest także grupa tzw. sportowców-amatorów (w dosłownym rozumieniu tego terminu), którzy nie traktują swojego uczestnictwa w zawodach jako aktywności zarobkowej.

${ }^{2}$ Należy zaznaczyć, że zgodnie z Ustawa o sporcie z dnia 25 czerwca 2010 r.: „,sportem są wszelkie formy aktywności fizycznej, które przez uczestnictwo doraźne lub zorganizowane wpływają na wypracowanie lub poprawienie kondycji fizycznej i psychicznej, rozwój stosunków społecznych lub osiągnięcie wyników sportowych na wszelkich poziomach". Oznacza to, że współzawodnictwo może, ale nie musi być atrybutem aktywności sportowej.
} 


\title{
Bibliografia
}

BOŃCZAK B., 2013a, Turystyka aktywna, kwalifikowana czy sportowa? Wzajemne relacje między zjawiskami w świetle literatury polskiej i zagranicznej, [w:] Wspótczesne uwarunkowania i problemy rozwoju turystyki, R. Pawlusiński (red.), Wyd. Uniwersytetu Jagiellońskiego, Kraków, s. 121-134.

BOŃCZAK B., 2013b, Aktywne formy turystyki - problemy terminologiczne, [w:] Nowe-stare formy turystyki w przestrzeni, R. Wiluś, J. Wojciechowska (red.), ser. „Warsztaty z Geografii Turyzmu”, 3, Wyd. Uniwersytetu Łódzkiego, Łódź, s. 49-62.

GIBSON H.J., 1998, Sport tourism: a critical analysis of research, „Sport Management Review”, 1, s. 45-76.

MOKRAS-GRABOWSKA J., 2015, Różnorodność metod teoretycznych i form podejść w turystyce aktywnej, [w:] Badania nad turystyka. Jeden cel, różne podejścia, B. Włodarczyk, M. Makowska-Iskierka (red.), ser. „Warsztaty z Geografii Turyzmu”, 6, Wyd. Uniwersytetu Łódzkiego, Łódź, s. 117-129.

ROGALEWSKI O., 1974, Zagospodarowanie turystyczne, Wyd. Szkolne i Pedagogiczne, Warszawa.

Ustawa z dnia z dnia 25 czerwca 2010 roku o sporcie, Dz. U. 2010, nr 127, poz. 857.

\author{
Dariusz Ilnicki \\ Uniwersytet Wrocławski \\ Małgorzata Pstrocka-Rak \\ Akademia Wychowania Fizycznego we Wrocławiu \\ Izabela Gruszka \\ Akademia Wychowania Fizycznego we Wrocławiu
}

\section{TURYSTYKA SPORTOWA - GŁOS W DYSKUSJI}

Zdaniem M. WEEDA (2009) pojęcie turystyki sportowej funkcjonuje w literaturze naukowej od lat 60. XX w., a to za sprawą pracy D. ANTHONEGO (1966). Tym samym wydaje się, że dyskusja nad tym, czy takie pojęcie i zjawisko jest i występuje, w pewnym sensie, byłaby wyważaniem już otwartych drzwi. Jednak cały problem koncentruje się wokół definicji pojęcia, dookreślenia tego, co będziemy pod tym terminem rozumieli. Ostatecznie, czy miałaby to być definicja uniwersalna, czy "tylko" operacyjna za każdym razem? Stwierdzić należy, że pomimo 50-letniej historii stosowania tego terminu nadal w różny sposób jest on definiowany.

Znaczna część badaczy określa granice turystyki sportowej bardzo szeroko (m.in. GAWORECKI 2008, GIBSON 1998, 2003, KAZIMIERCZAK, MALCHROWICZ-MOŚKO 2013, MALCHROWICZ 2012, Standeven, DeKnop 1999, cyt. za: BRENT, DARYL, red. 2004). Przyjmują oni, że są to wszelkie formy czynnej aktywności ruchowej, jak również bierne uczestnictwo w imprezach sportowych i sportowo-rekreacyjnych, które związane jest z koniecznością zmiany miejsca swojego codziennego otoczenia. Co istotne, zmiana ta może wynikać z konieczności podjęcia obowiązków zawodowych $^{1}$ (np. sportowcy wyczynowi) czy być podejmowana w ramach czasu wolnego (sportowcy amatorzy).

Inni autorzy zawężają znaczenie turystyki sportowej na przykład do formy aktywności turystycznej związanej z uczestnictwem $w$ imprezach sportowych, jako widz lub ich uczestnik (BRENT, DARYL, red. 2004, DZIĘGIEL, LUBOWIECKI-VIKUK 2013, HADZIK 2014, OLSZEWSKI 2010, BOŃCZAK 2013a, WOJDAKOWSKI, FORMELLA 2009, WYRZYKOWSKI, MARAK, red. 2010). Turystyka sportowa to również zwiedzanie obiektów sportowych (np. stadionów, skoczni narciarskich) zbudowanych współcześnie lub będących elementem dziedzictwa historycznego, jak również zwiedzanie muzeów sportu (BRENT, DARYL, red. 2004). W ramach tego terminu umieszcza się czasami także wyjazdy, których głównym celem jest aktywny wypoczynek, np. uprawianie narciarstwa, kajakarstwa czy jeździectwa (Siwiński 2007, za: BOŃCZAK 2013b, TALEGHANI, GHAFARY 2014, MERSKI 2002).

W literaturze przedmiotu funkcjonuje kilka klasyfikacji turystyki sportowej. Najczęściej cytowana wyróżnia następujące formy, a mianowicie: aktywną turystykę sportową, "eventową" turystykę sportową oraz nostalgiczną turystykę sportową. Ta ostatnia odnosi się do zwiedzania historycznych i współczesnych obiektów sportowych oraz muzeów sportu (BERBEKA 2010, BRENT, DARYL, red. 2004, FUNK, BRUUN 2007, ISKRA, WALASZCZYK 2015).

W konsekwencji studiów literaturowych i przedstawionych powyżej spostrzeżeń dotyczących określania terminu „turystyka sportowa”, chcielibyśmy przedstawić propozycję jej zakresu treściowego (rys. 1). W przypadku naszej propozycji konieczne jest szerokie podejście do rozumienia i definiowania pojęcia "turystyka sportowa”. Tym samym pod tym pojęciem można rozumieć podróżowanie poza miejsce codziennego funkcjonowania, na okres maksymalnie jednego roku, kiedy przynajmniej jednym z głównych motywów wyjazdu jest:

${ }^{1} \mathrm{~W}$ takim ujęciu zdaje się to przeczyć definicji turysty/turystyki, która nie jest związana z wykonywaniem obowiązków zawodowych. 